\title{
“UM SÁBADO EM 30": MEMÓRIA E FICÇÃO
}

Igor de Almeida Silva ${ }^{1}$

Resumo: Neste ensaio, estudamos a peça Um sábado em 30, de Luiz Marinho, tendo como eixo a relação entre memória e ficção. A partir desse pressuposto, apontamos alguns elementos do processo criativo de Marinho e desvelamos significações várias da obra (de uma sociedade de "coronéis e arlequins" a uma "comédia do patriarcalismo"), mostrando seus procedimentos estéticos e sua ideologia.

Palavras-Chave: Memória e ficção, Coronéis e arlequins, Comédia do patriarcalismo.

Abstract: Based on the relationship between memory and fiction, this essay analyses the play Um sábado em 30, by Luiz Marinho. It points to certain elements of Marinho's creative processes and unveils various meanings of the play (from a representation of a society of "colonels and harlequins" to a "patriarchal come$\left.d y^{\prime \prime}\right)$, demonstrating the author's aesthetic procedures and ideology.

Key Words: Memory and fiction, Colonels and harlequins society, Patriarchal comedy.

\section{INTRODUÇÃO}

Um sábado em 30 foi a primeira peça escrita por Luiz M arinho e também sua obra mais famosa, tanto pelos prêmios recebidos quanto pelo sucesso alcançado junto ao público com a montagem pioneira do Teatro de Amadores de Pernambuco (TAP), estreada no Recife, no Teatro de Santa Isabel, no dia 8 de julho de 1963. Recolhendo material para sua escritura desde 1954, Marinho apresenta uma primeira versão do texto para Valdemar de Oliveira, fundador e diretor artístico do TAP, entre fins de 1960 e inícios de 1961, recebendo tempos depois um parecer positivo em que o diretor atesta as qualidades do texto e reconhece o nascimento de um novo dramaturgo. Reconhecimento que se confirmaria posteriormente com a encenação realizada pelo TAP de Um sábado em 30.

Eis uma obra controversa que despertou a admiração e a desconfiança de críticos. Nascida sob o signo da memória e da saudade, segundo seu próprio autor, foi uma tentativa de reencontrar a gente de sua terra, e por isso mesmo terminou sendo qualificada por muitos de seus contemporâneos como etnográfica, saudosista e autobiográfica, sem que se ressaltassem devidamente suas qualidades estéticas. Da memória à ficção. Do voltar-se ao passado à des-

1 M estre em Letras/Teoria da Literatura, pelo Programa de Pós-Graduação em Letras e Lingüística, da Universidade Federal de Pernambuco - UFPE. Endereço eletrônico: ialmeidasilva @uol.com.br. 
coberta de sua alteridade. Este é o itinerário marinho; este é nosso percurso em busca de sua ficcionalidade.

\section{MEMÓRIAS FICCIONALZADAS}

Em Luiz Marinho: o sábado que não entardece, Tenório Vieira indica que o fio condutor de sua análise deu-se na perspectiva de costurar a obra marinha como a memória ficcionalizada do autor: "Uma ficcionalização que se manifesta ora como lembranças, ora como recriações de histórias ou estórias ouvidas e aprendidas na infância ou adolescência, ou como confissões pessoais" (2004, p. 18). Como ele mesmo diz, "as memórias marinhas" são

Memórias ficcionalizadas, entenda-se bem, pois seu teatro encerra um conjunto de lembranças - domésticas, sociais, políticas, afetivas, culturais e religiosas que ao tempo em que foram diluídas em quatorze textos, são também costuradas e entrelaçadas por um delicado fio: o do olhar de um Luiz Marinho adulto sobre a criança e o jovem que um dia fora; um M arinho solipcista que busca dar sentido à sua existencialidade e, por sua vez, a todo o universo que o cerca e que o viu nascer, crescer, tornar-se adulto, envelhecer e caminhar para a morte (2004, p. 18).

Mas observe-se que a chave de interpretação da obra marinha como memórias ficcionalizadas é o próprio Marinho quem fornece em Um sábado em 30:

Quando fui menino, tinha o gosto pouco comum de andar pela cozinha misturado com os empregados e passar horas e horas escutando-os conversar. Muitas vezes, desejei ser do mato e participar daquelas estórias, daquelas pelejas por eles contadas. Agradava-me sobremodo, seu linguajar e introduzia-o em minhas palestras - tenência, sobrosso, vigie, cuidei, caçuar, etc, com freqüência tal que deu trabalheira imensa à minha família, corrigir-me.

Aos sábados, ninguém me arredava da cozinha. Era o dia em que chegavam do mato para a feira, os parentes dos empregados e iam "assistir" lá em casa... Ai! Que gostosura de linguagem, de palestra!... E eu ali atento, sorvendo, vibrando... até que o sol esfriava e eles "marchavam 'para trás"...

Outra intenção não tive, ao escrever esta pecinha, a não ser a de evocar um pouco um sábado lá em casa, e homenagear aquela gente que eu quero muito bem, e que anda por aí dispersa sem que jamais possa revê-la novamente... (M ARINHO, 1968, p. 17).

Todavia, a declaração de "evocar um pouco um sábado lá em casa" ia além desta abertura à sua peça, só publicada em 1968. Quando de sua première pelo TAP, havia ele publicado esse mesmo texto no programa da montagem. Talvez por isso Um sábado em 30 foi tomado, por praticamente todos os críticos, como um texto urdido "sob o prisma da recordação" (PONTES, 1963, p. 3); "evocação terna e galhofeira do passado" (PRADO, [1963] 2002, p. 273). Jul- 
gamento que será reforçado, posteriormente, pelo próprio Marinho, em depoimentos e entrevistas para a imprensa. Porém, é no seu discurso de posse, na Academia Pernambucana de Letras, em 1980, que o dramaturgo confirma, definitivamente, a importância da memória - suas lembranças da infância e adolescência em Timbaúba - não só em Um sábado em 30, mas na elaboração de toda sua obra dramática até aquele momento, especificando as fontes e os motivos que originaram cada peça ou determinados personagens.

$\mathrm{Na}$ época, seu discurso propiciou comentários como o de Nilo Pereira que fez a seguinte afirmação: "Pelo discurso de Luiz Marinho percebe-se claramente que as suas peças são autobiográficas. 0 que ele retrata é sua infância, a sua adolescência em Timbaúba e adjacências" (1980, [s/p]). Ou o de Andrade Lima Filho para quem a peça contém "episódios duma narrativa em que já se identifica no teatrólogo de hoje o memorialista de amanhã, com a mesma graça, leveza e humor no artesanato literário" (1981, [s/p]). Este é o tom de vários artigos publicados na imprensa recifense. Foi assim que Tenório Vieira cunhou o termo memórias ficcionalizadas como viés interpretativo de seu livro: retomando e redimensionando o papel da memória no teatro de Luiz Marinho, a partir dos depoimentos do autor sobre sua obra e da opinião de seus contemporâneos.

Para o ensaísta, Um sábado em 30 tanto impulsionou a carreira dramatúrgica de Luiz Marinho, como se constituiu ela mesma numa obra "que vai orientar tanto estético quanto sistematicamente, muitos dos caminhos da sua produção ulterior" (VIEIRA, 2004, p. 93). É importante trazer à cena trechos de uma entrevista concedida em 1987, na qual Marinho reitera a singularidade destas suas memórias ficcionalizadas, que para ele só estariam presentes em Um sábado em 30: "Quanto ao autobiográfico e o fantasioso, não há o autobiográfico. Só em 'Um sábado em 30' é que há uma mistura, pois foi uma espécie de saudosismo da infância" (MARINHO, 1987, p. 9-10).

Podemos observar que Marinho tem a consciência de que sua dramaturgia, embora a tomem como autobiográfica, é exclusivamente fantasiosa, abrindo exceção apenas para Um sábado em 30, que ele considera como uma mistura entre a autobiografia e o fantasioso. No entanto, é necessário ressaltar que o caráter que Luiz M arinho imprime a esse termo é um tanto impreciso, caso levemos em consideração a diferença que Luiz Costa Lima (1986) estabelece entre fantasia e imaginário. Entende-se a fantasia, dentro do terreno da ficção, como a capacidade de apagar a realidade desagradável e substituí-la por uma outra que, pertencendo à mesma ordem da realidade vivida, ou seja, pautando-se no real, nega a realidade anterior em detrimento de um hipotético presente mais agradável. Dessa forma, ela se caracteriza como uma ativida- 
de compensatória do "eu" que, através do uso exclusivo de mecanismos de identificação (imitação do real ou do cotidiano), abstrai qualquer outro elemento que possa impedir o processo de reconhecimento do leitor-espectador com o objeto artístico. Por isso, além de compensatória, ela é sentimental, não abrindo espaço para o questionamento e a criticidade. Ela seria um poético facilitado, no qual as narrativas da cultura de massa constituiriam seu melhor exemplo.

Para Costa Lima, a fantasia não constituiria o verdadeiro terreno do ficcional. Em verdade, o ficcional corresponderia ao imaginário, à irrealização da realidade. Ao invés de criar uma realidade substitutiva, o imaginário produz e justapõe uma outra de maneira espelhar que não reflete necessariamente a realidade primeira, mas revela uma imagem outra distorcida que a põe em questão. Ė o surgimento de uma outra possibilidade que não é, entretanto, compensatória, mas instauradora do desequilíbrio. Ou seja, o imaginário seria a criação do autor de sua alteridade, suas possibilidades de vir a ser que se realizam na irrealização imaginária de seu teatro mental e que, por sua vez, ganham forma na elaboração poética. Poderíamos dizer também que o imaginário se opõe à fantasia justamente por transgredir o real. Dessa forma, concluímos que o fantasioso ao qual Marinho se refere diz respeito ao imaginário pressuposto por Costa Lima em seu livro Sociedade e discurso ficcional (1986). Imaginário que confere 0 estatuto de ficcionalidade de uma obra. Sobre Um sábado em 30, Marinho faz a seguinte afirmação na entrevista:

Gostaria de falar sobre minha primeira experiência de teatro que foi Um sábado em 30, minha primeira peça. Situei nela o ano 30 para ter como "pano de fundo" a revolução, mas em trinta eu tinha cerca de três anos de idade, sendo assim, os personagens foram todos inspirados mais tarde, eles nasceram todos de minha vivência com o pessoal de Timbaúba e até mesmo com parentes, embora estejam disfarçados na peça. Usar este "disfarce" em meus personagens de UM SÁBADO EM 30 foi influência de minha mãe, pois ela considerou, na época, que mostrá-los sem máscaras iria chocar a gente de nossa terra. Se não tivesse sido a observação dela, a peça poderia ser desdobrada em até três, pois era enorme. Para mim não foi fácil decidir se deveria ou não colocar "disfarces" naquela gente, por isso a peça ficou engavetada ainda um bom tempo (MARINHO, 1987, p. 8).

Observe-se que o autor apenas acentua de que maneira elaborou suas memórias ficcionalizadas. A máscara, que na ficção surge para desvelar o outro que em verdade não se é, em Luiz M arinho assume a conotação primordial de disfarce. Em sua fala, a memória é maquiada pela ficção, não para revelar sua alteridade, mas para ocultar sua origem documental e memorialística. Ou seja, proteger sua gente de futuros constrangimentos: de se ver e ouvir diante de 
um palco de espelhos; testemunhar seus segredos, seus hábitos e suas crenças sendo desvelados. E por fazerem parte de uma comunidade, temem suas sanções. Eis um veto social (e maternal) que origina um segundo veto: 0 veto à memória. Dessa forma, pode-se dizer que, na ficcionalização de suas memórias, Marinho, buscando preservar seu "povo", "sem querer", trilhou o caminho rumo à sua alteridade.

\section{A TESSITURA DOS FATOS}

Um sábado em $30^{2}$, comédia em três atos, tem sua ação concentrada na ante-sala de jantar da casa citadina de um senhor de engenho do Partido Liberal, Seu Quincas, e de sua esposa, D. Mocinha, no interior do Nordeste, mais precisamente, na zona da Mata Norte de Pernambuco, em Timbaúba, cidade em que nasceu e cresceu Luiz Marinho, seu autor. Como diz o título, a peça é situada no ano de 1930, durante os últimos dias da revolução de outubro. Sua duração respeita uma unidade de tempo rigorosa que não ultrapassa um dia e meio, começando na manhã de um sábado e terminando na manhã do dia seguinte juntamente com o anúncio do fim da revolução e o retorno do filho "pródigo", Vasco, que partira para a guerra.

Neste lugar, vivem também Romeu, M ercês, Maria de Jesus e Leninha, filhos do casal; Quitéria, vitalina e irmã de D. Mocinha, e o Major Paulino, veIho cego de 85 anos reminiscente da Guerra do Paraguai, sogro de Seu Quincas, pai de Quitéria e de D. Mocinha. Incluem-se ainda os empregados, profundos conhecedores da vida dentro e fora da casa, verdadeiros cronistas da intimidade familiar e do cotidiano timbaubense. Eles são Sá Nãna, velha octogenária, bisbilhoteira, ao mesmo tempo empregada e membro da família, ou seja, uma espécie de agregada da casa; Filó, a nova copeira; Zefa, dançarina de pastoril; Joana; Chico e Julião. Além desses, passam pela casa outros personagens vindos da cidade (o bicheiro Seu Severiano), dos arredores da residência sem uma definição específica de sua relação com o núcleo familiar (o menino Juca, que serve de acompanhante do Major Paulino ${ }^{3}$ ) ou do mato (as comadres de D. Mocinha denominadas apenas de Duas Mulheres ${ }^{4}$ ). São personagens

2 Existem duas versões de Um sábado em 30. Cf. MARINHO $(1968,1986)$. A primeira versão é mais extensa e de maior dramaticidade, enquanto que na segunda há maior concisão e prevalece a comicidade. Aqui, usamos as duas versões em função das necessidades próprias a cada âmbito deste ensaio.

Na edição de 1986, o personagem Juca foi suprimido do texto pelo autor.

4 Na edição de 1968, as Duas Mulheres aparecem acompanhadas de duas crianças, um menino e uma menina, que não aparecem na relação de personagens e também não possuem falas no corpo do texto. Só tomamos conhecimento da existência de ambos pelas didascálias e pelas falas de outros personagens. Na edição de 1986, eles são suprimidos do texto, permane- 
sempre dependentes da generosidade senhoril, retribuindo seus favores através de sua fidelidade e de amorosos "agrados". Seguem a ideologia do favor como fundamento de sua organização social, fruto de nossa herança patriarcal e que no Brasil configurou-se, sobretudo, durante a Primeira República, na forma do coronelismo ${ }^{5}$.

Num sábado em 30, às vésperas do desfecho da Revolução, a família de Seu Quincas e de D. M ocinha encontrava-se mergulhada em questões domésticas e familiares: anunciava-se o fim do conflito para os próximos dias e D. Mocinha, além de sofrer pela ausência de notícias do filho na guerra, preocupava-se com a educação das filhas Mercês e Maria de Jesus que andavam muito "libertinas", só pensando em namoro (Maria de Jesus, inclusive, namorava um artista de circo); afora isso, pairava o mistério do roubo do dinheiro da feira, recaindo a suspeita sobre a nova empregada (Filó); preparava-se o batizado de mais um afilhado de Seu Quincas e D. Mocinha para o domingo; Sá Nãna, a todos vigiar - patrões e empregados; Zefa a rebolar "as cadeiras" pela casa, faceira e zombeteira; Quitéria a tripudiar do amor de Seu Severino; Major Paulino que vive de contar seu passado e a falar de guerra, não deixava de passar a mão no traseiro de quem dele muito se achegava, e o Romeu, Don Juan das empregadas, dedicava-se com afinco em desencaminhar "moça direita". Sua última conquista foi Filó. Quando descoberto, ia sendo obrigado pelo pai a casar-se com a moça, como forma de "reparação", se não fosse o intermédio de Sá Nãna que falou o que não devia, revelando os assédios de Seu Quincas com a cozinheira Joana (o gosto pelas empregadas já era antigo na família). Ao invés de sanar a crise, a velha bisbilhoteira apenas colocou mais lenha na fogueira. Indignada, D. M ocinha ameaçou sair de casa (não suportou a quase traição do marido com uma empregada nem a idéia de ver seu filho casado com outra empregada) e Major Paulino jurou vingança (as desavenças parentais costumam acabar em sangue!). Além disso, o circo foi embora e Maria de Jesus ficou de coração partido, sem seu namorado. Os empregados também não se entendiam mais: Julião e Chico brigaram pelo amor da pastora Zefa que não se interessava por outra coisa a não ser soldado e pastoril. Aliás, a pastora estava sempre a rir de tudo e de todos, pois como ela mesma dizia, "esta casa é mesmo uma comédia"; depois foi-se "embora num bonde cheinho

cendo apenas como assunto das conversas. Além disso, nessa mesma edição, as Duas Mulheres são condensadas num único personagem chamado Luzia.

5 Segundo Maria Isaura Pereira de Queiroz (1977), o coronelismo, entre outras características, define-se como um sistema político baseado na solidariedade mútua entre membros de uma mesma parentela e na proteção de seus eleitores, ou seja, de sua gente, onde a figura do coronel (título atribuído popularmente a personalidades de importante influência política e econômica numa determinada localidade) goza de grande prestígio. 
de soldado" (M ARINHO, 1986, p. 62). A paz só foi restituída com o anúncio do fim da Revolução e a chegada de Vasco que não era mais herói de guerra, mas da mãe, do pai, do avô, do irmão, das irmãs, ou seja, o herói da família. Estavam todos prontos para o próximo sábado, mais um sábado em 30.

\section{CRÔNICAS MARINHAS}

Como pudemos perceber Um sábado em 30 é sustentado por uma tênue intriga que se ramifica e se fragmenta em diversas subintrigas que ora se encadeiam, ora independem entre si. Há uma seqüência de minidramas, e em/entre cada um deles uma minicomédia, misturando simpatia extrema por seus personagens e exposição bem humorada de seus ridículos. Essas pequenas unidades dramáticas, que se organizam de maneira dispersa e independente, justapondo-se progressivamente até o desenlace da peça, constituem um mosaico de vivências dos personagens que entram e saem da casa (seus habitantes e visitantes), estabelecendo um jogo que ora provoca uma "impressão de real", efeito de real; ora subverte sua lógica, produzindo sua contraface, 0 irreal e 0 non-sens. M arinho apenas finge respeitar a lógica do real, porque sua força cômica obriga-o a manter ciosamente seu desejo à subversão e ao absurdo, características estas pertencentes à comédia. Todavia, permanece fiel a uma estética do cotidiano que, ao mesmo tempo em que reforça sua filiação ao gênero cômico, aproxima Um sábado em 30 da crônica: registro poético e geralmente irônico que capta o imaginário coletivo em suas manifestações cotidianas. Apreende 0 instante tal como ele se apresenta, fragmentado, perenizando-o.

Joel Pontes, numa crítica sobre a montagem do TAP de Um sábado em 30, já apontava que essa peça configurava-se como "a crônica de uma família patriarcal, com seus numerosos aderentes e amigos" (1963, p. 3). No entanto, a crônica marinha não se restringe à família, mas se estende a todos aqueles que compõem seu universo sócio-cultural, isto é, os empregados. Alias, é importante frisar que a família patriarcal, assim como toda a pequena sociedade que a rodeia, é apresentada ou narrada ao leitor-espectador sob a perspectiva desses mesmos personagens. Não é necessariamente a família que ganha 0 primeiro plano em Um sábado em 30, mas seus empregados e agregados. Recontam para si mesmos e para o leitor-espectador suas venturas e desventuras dentro e fora da casa, intercalando passado e presente; comentam as peripécias dos patrões, vizinhos e conhecidos; brigam e se divertem entre si mesmos quase que simultaneamente, sempre com muito humor e ironia, indo do maravilhoso ao corriqueiro e que misturam no seu discurso ingenuidade e malícia, censura e indulgência. São cronistas matutos que narram o cotidiano ao sabor telúrico em que se configuram as memórias ficcionalizadas de Luiz M arinho. 


\section{CORONÉIS E ARLEQUINS}

Todos os integrantes da casa são adeptos da Aliança Liberal, embora só o velho Major pareça ser o mais engajado de todos os membros da família, beirando muitas vezes ao ridículo, tal é o seu fervor revolucionário. Nesta casa, existem duas parentelas afins, ligadas pelos laços matrimoniais que uniram Seu Quincas a D. M ocinha. A primeira é representada por Seu Quincas, um homem austero e autoritário, que possui grande prestígio na cidade e em suas redondezas, agregando uma grande quantidade de compadres, comadres e afilhados, além de seus empregados. Usando palavras de Pereira de Queiroz, essa é a sua gente.

A segunda parentela pode ser representada pelo Major Paulino, patriarca de uma tradicional família da Paraíba: os Teixeira Cavalcanti. Major Paulino fora voluntário na Guerra do Paraguai, de onde Ihe vieram o título de Major e um olho cego. Pela patente marcial, percebe-se que não é um grande coronel, mas um líder local de segundo escalão que, provavelmente, pela escassez de suas posses quando jovem, ao ir para a guerra, não pôde receber um título maior $^{6}$. Inclusive, apesar de descender de uma família tradicional, insinua-se que sua fortuna fora adquirida de maneira ilegal na Guerra do Paraguai.

Se Major Paulino e Seu Quincas representam o universo masculino dessa sociedade, Dona M ocinha apresenta-nos sua contraparte feminina. Através de sua presença pode-se conhecer outros aspectos da classe da qual descende no que concerne ao papel reservado à mulher, sua formação e sua subjetividade. D. M ocinha reflete a típica mulher de boa família no interior do Nordeste. Restrita ao lar, suas únicas e principais preocupações limitam-se à educação dos filhos e à manutenção da casa. Rigorosa na educação moral das filhas, tenta Ihes impingir o recato sem muito sucesso. Quanto aos filhos, demonstra total abnegação e subserviência.

Como complemento a este universo patriarcal, justapõem-se aos "coronéis" seus empregados e agregados. Personagens que vivem à sombra de seus patrões, recolhendo dos seus serviços e pequenos favores o sustento para sua existência. Conquistam o bem-querer de seus senhores na esperança de dias melhores. Ao mesmo tempo, são personagens ambíguos que, em sua conduta e em suas confissões, revelam a revolta e o conformismo, a subserviência e a transgressão ao seu status quo de oprimidos. E o riso torna-se seu principal instrumento de subversão da realidade, utilizando-se do escárnio, dos chistes e da ironia para triunfarem sobre seus mestres e do humor para vencerem seu

6 A terminologia marcial (coronel, major, etc.) rege as relações entre as diversas parentelas e seus respectivos membros como uma forma de demarcação do papel que cada integrante ocupa nessa sociedade. 
próprio desassossego. Possuem a ambigüidade do arlequim, servo e carrasco de seus amos, que deles se serve para melhor se divertir, além de também deterem a lucidez e a loucura do bufão, sempre a se fazer de bobo diante dos poderosos, mas também pleno de sabedoria, aconselhando seus reis nos momentos de insensatez e desgraça.

0 conformismo dos empregados em Um sábado em 30 manifesta-se, notadamente, através do personagem de Sá Nãna, guardiã da moral na casa. Sua visão de mundo restringe-se ao conhecimento das obrigações e limitações da mulher e dos direitos do homem, assim como o lugar que o empregado deve ocupar na casa. Nela, não existe nenhuma crítica ou revolta em relação à sua condição de subalterna ou à de seus demais companheiros, nem questiona a moral patriarcal que é tão severa com as mulheres e indulgente com os homens. Em verdade, ela age a favor desse sistema. Descende diretamente desse universo, onde nasceu, cresceu e envelheceu, enxergando a mulher apenas no seu decoro, no seu dever de se guardar constrita até o dia do casamento e nas suas obrigações para com a família e a religião. Em oposição a este universo, existe o homem e sua sexualidade latente da qual Sá Nãna não recrimina de todo, mas que se configura sempre como uma ameaça à moral e, sobretudo, às mulheres. Para Sá Nãna, todos os homens são iguais, "é mesmo que pólvora, o fogo acolá e eles já estão se acendendo" (M ARINHO, 1968, p. 71).

Assim como Sá Nãna, Filó também encontra-se estagnada no conformismo social. Permanece passiva diante da exploração e da humilhação que Ihe impingem. Depois de ser seduzida por Romeu, Seu Quincas ainda tenta casá-la com o filho e preservar sua honra, mas a moça não aceita. Diz que prefere continuar pobre e solteira. Filó é o personagem que mais sofre a ação de outros personagens. Tudo com ela acontece. Logo que chega, torna-se suspeita de um roubo; em seguida, é assediada pelo filho do patrão; é repreendida por Sá Nãna que violentamente a coloca no seu lugar de empregada e destrói seus sonhos de casamento e ascensão social; minutos depois, é alçada ao status de noiva de Romeu por Seu Quincas, tornando-se alvo do ódio de D. Mocinha que não admite ver o filho casado com uma "empregadinha"; finalmente, vai embora, acompanhada de seu noivo tropeiro que viera buscá-la a mando de Romeu. Filó passa apenas praticamente 24 horas na casa e, mesmo assim, sofre todos esses transtornos, sem de fato haver alguma modificação em seu espírito. Continua a empregada subserviente, conformada à sua condição de subalterna. Lembra um desavisado arlequim, destituído de malícia e astúcia, que serve de joguete para as disputas entre seus amos. Não há em seu discurso nenhum momento de questionamento. Ela não se pergunta o porquê da 
vilania de Romeu, nem chega a desejar uma vingança pelo mal que sofreu. Também não pede ajuda a ninguém. Permanece resignada à sua sina.

Em sua subserviência, no entanto, cultivam também a astúcia, já que alguns desses empregados lembram os antigos servos dos jovens senhores enamorados da tradição do teatro cômico que, diante dos obstáculos às suas realizações amorosas, contavam com o seu fiel apoio; desde a comédia nova com seus escravos e parasitas, passando pelo zanni da commedia dell'arte, os criados de Molière e os arlequins de Marivaux. Chico e Zefa, por exemplo, retomam esse legado, servindo de alcoviteiros para as peripécias amorosas tanto de Romeu quanto de Maria de Jesus, respectivamente.

Porém, se do conformismo vem a subserviência, da revolta origina-se a transgressão. Nessa dialética transitam alguns de nossos arlequins. Ao mesmo tempo em que são subservientes aos seus amos, subvertem a lógica da dominação pela força do riso. Manifestam seus instintos hostis através de chistes tendenciosos que atuam como uma forma de agressão, disfarçada pelo jogo de palavras. Fazem rir ao invés de agredir. Aliás, o riso em si já é uma forma de agressão. Geralmente, as vítimas de seus gracejos são personagens ridículos e, por isso, passíveis de escárnio, e que não Ihes representam nenhuma ameaça, já que possuem pouca autoridade na casa. Esses personagens são Quitéria e Major Paulino. A vitalina seria a principal vítima de seus gracejos, sobretudo para Chico e Zefa. No momento em que está de partida para a feira, Quitéria chama Chico para acompanhá-la, enquanto "se ajeita" diante do espelho. Nesse instante, 0 arlequim matuto diz com deboche, ao ser chamado pela solteirona:

\footnotetext{
QUITÉRIA - (Fica no espelho, se ajeitando) Chico. Traga o balaio e vamos saindo pra feira.

CHICO - (Entrando, fica olhando a situação) Está vendo, Dona Mocinha? Essa tem coragem. Me desculpe, dona M ocinha, mas se eu tivesse essa cara, eu andava de ré (M ARINHO, 1986, p. 45).
}

Todavia, nem sempre essas revanches têm ares de simples ditos espirituosos. Além disso, nossos arlequins usam do humor como forma de triunfo e denúncia à divisão social que os oprime e revolta. É através do duplo sentido e da malícia, inseridos nas jornadas de pastoril, que eles expõem as diferenças de classe que existem em sua sociedade, ao mesmo tempo em que triunfam sobre a angústia, tirando de seu desassossego motivo de riso e reafirmação de si mesmos. No riso e no escárnio do patrão, 0 arlequim é sempre o vencedor, mesmo que na sua alegria resida submerso o pessimismo e 0 amargor de sua existência. 


\section{A COMÉdia do Patriarcalsmo}

Em Um sábado em 30, o verdadeiro nó da trama que, conseqüentemente, deflagra a crise que envolverá toda a família e os empregados, dá-se quando Sá Nãna revela a Seu Quincas e a D. Mocinha o envolvimento "amoroso" de Romeu e Filó. A reação do patriarca de tentar obrigar o filho a casar-se com a empregada provoca-nos, entretanto, um certo efeito de estranhamento. Como pode um senhor de engenho dos anos 30, guardião e centro de uma ancestral estrutura social extremamente rígida e excludente, abandonar preconceitos de classe e de gênero em prol de ideais de igualdade, posicionando-se declaradamente contra qualquer "mania de tradição", numa sociedade em que prepondera a preservação das tradições?

No seu discurso, Seu Quincas age como se, ele próprio, estivesse carregado de culpa, como se estivesse a compensar através do castigo do filho uma falta que outrora ele mesmo cometera e que permaneceria latente em sua consciência, atormentando-o. Hipótese que se confirma quando é descoberto seu assédio à cozinheira Joana.

No desvelamento de seu "deslize", abala-se sua moral, fazendo-o perder, momentaneamente, a autoridade sobre a família, sobretudo, sobre sua esposa. Destrói-se o primeiro pilar dessa família e dessa sociedade: o patriarca. Percebe-se, portanto, um típico procedimento cômico, no qual se pulverizam todos os falsos moralismos, com um olhar, cuja força "puxa para baixo" tudo 0 que se encontra em cima, instalando a crise, cindindo, criando rachaduras em toda a superfície de imagem solene e polida. Bem próprio da comicidade em geral de Bergson ([1900] 2004) que denuncia o que é rígido e artificial, assim como da força cômica, concebida por Cleise M endes (2000).

Além disso, D. M ocinha, que se fazia perceber até então como a esposa virtuosa e submissa, abnegada aos filhos e generosa com os seus empregados, revela na última cena da peça a fragilidade de sua imagem "candidamente construída". A matriarca não se apieda do sofrimento de Filó, pois permanece obcecada na tradição da família, na humilhação que seria ver seu filho casar-se com uma moça pobre e perdida. Reflete os princípios dessa sociedade, sem solidarizar-se. Quando questiona a resolução do marido, esses são seus argumentos: "- Mas Seu Quincas, o senhor quer tomar a medida máxima! Não está vendo a impossibilidade?!... A diferença? Ela é uma empregadinha..." (MARINHO, 1968, p. 117).

Não se reconhece mais em D. Mocinha, ao chamar Filó de "empregadinha", a mulher que, no começo da peça, fazia o seguinte tipo de afirmação sobre suas comadres do mato: "- Sabe que é uma gente de brio! Quisera que as minhas amizades aqui na rua, fossem tão sinceras quanto dessa gente!" 
(M ARINHO, 1968, p. 43). Tal paradoxo reforça as contradições dessa sociedade que baseia suas relações pessoais, nas questões de trabalho, sobretudo, na dependência e no favor. Quando tudo isso é transcendido e vislumbra-se a possibilidade de uma pessoa humilde como Filó ascender ao mesmo status de D. Mocinha, essas ternas relações de amizade e dependência, que condicionam a dialética entre o patrão e 0 empregado, são colocadas em suspensão em detrimento da segregação de classes, dos velhos preconceitos que baseiam a sociedade patriarcal brasileira. Portanto, não é só o marido que é desmascarado, mas também a matriarca. Cai o segundo pilar da família e do patriarcalismo em Um sábado em 30.

Sobre Um sábado em 30 paira o espírito de Casa-grande \& senzala, de Gilberto Freyre, exatamente porque o livro trata da história intima da sociedade brasileira, seus primórdios, de uma vida doméstica e conjugal, onde se viveu sob o patriarcado escravocrata, polígamo, mas cristão, num cristianismo circunscrito ao cotidiano da família, rodeado pelas crendices e pelos ritos dos escravos e que, em sua miscigenação, erigiu as bases de nossa organização social e de nosso imaginário, nossa subjetividade. Esse é o pensamento que sobrevoa a obra em questão, de maneira fantasmal, mas que muito ilustra a reconstituição e a análise que Gilberto Freyre fez da sociedade patriarcal brasileira. Eis as palavras do sociólogo que reforçam nossa observação:

Nas casas-grandes foi até hoje onde melhor se exprimiu o caráter brasileiro; a nossa continuidade social. No estudo da sua história íntima despreza-se tudo o que a história política e militar nos oferece de empolgante por uma quase rotina de vida: mas dentro dessa rotina é que melhor se sente o caráter de um povo. Estudando a vida doméstica dos antepassados sentimo-nos aos poucos nos completar: é outro meio de procurar-se o "tempo perdido". Outro meio de nos sentirmos nos outros - nos que viveram antes de nós; e em cuja vida se antecipou a nossa. É um passado que se estuda tocando em nervos; um passado que emenda com a vida de cada um; uma aventura de sensibilidade, não apenas um esforço de pesquisa pelos arquivos (FREYRE, [1933] 2000, p. 56).

Como Marinho pode ser acusado de saudosista - como tantos críticos o julgaram - , de restringir-se a um "lirismo de situações" se os alicerces da sociedade que ele apresenta - o patriarca e a matriarca - são colocados abaixo, levando consigo tudo o que se encontrava por cima em sua solenidade? Partes desse sistema, ambos contribuem para a manutenção desse ancestral modelo de organização social, misturando nessa mesma "panela velha" preconceitos de raça, gênero e classe, repassando de geração em geração e propagando-os entre seus empregados e agregados, como prova a conduta de Sá Nãna que, além de resignar-se ao fatalismo social de sua existência, endossa-o 
entre seus pares, inclusive, como forma de exercício de poder, reproduzindo essa mesma prática, de subalterno para subalterno.

Como resolver essa situação se todos se revelam em sua hipocrisia e enrijecimento, se insistem na manutenção de seu status quo? Apenas a descida de um deus ex machina poderia levar a peça ao seu desenlace. $E$ de fato 0 Deus desce! Eis que surge Vasco. Seu retorno, que já era esperado desde 0 início de Um sábado em 30, possibilita a resolução da intriga, restituindo a paz naquela família e impondo drasticamente um desfecho à trama: seu happy end. Provisoriamente, coloca todos esses conflitos em suspensão. Esquece-se do que se passou e todos se reconciliam, inclusive, Seu Quincas e D. Mocinha. Assim como no restante do país com o fim da Revolução, a paz volta a reinar na casa (pelo menos até o fechar das cortinas).

Tal situação conota o próprio estado de uma sociedade dividida entre suas tradições e seu desejo de ruptura. Desejo frustrado. Por isso, acontece a suspensão dos conflitos através de um final abrupto e maniqueísta que impõe um desenlace harmonioso. Dessa forma, Marinho põe em discussão conflitos de classe, gênero e raça, apresentando-os em sua insolubilidade. Ele retrata as tensões e contradições de uma sociedade em transição, mas que se mostra incapaz de uma real transgressão de si mesma. Um sábado em 30 trata, portanto, da impossibilidade de transformação da sociedade patriarcal brasileira.

No entanto, deve-se levar em consideração que estamos a falar de uma comédia, que se vulgarizou pela crítica como uma comédia de costumes, pelo apreço de seu autor de registrar os aspectos pitorescos dos hábitos do matuto, seu linguajar e seus ritos. Nesse ponto, é necessário abrir um parêntese e discutir essa questão. 0 que é uma comédia de costumes? Esse tipo de comédia centra-se na pintura dos hábitos de uma sociedade, utilizando-se da sátira para chamar a atenção da platéia dos desvios, dos erros nos quais estariam correndo certos membros de um determinado segmento social. 0 riso surge como um censor que busca corrigir esses desvios de conduta. A comédia de costumes, portanto, expõe e critica os vícios de uma sociedade.

Em Um sábado em 30, os costumes dos matutos não são, em nenhum momento, ridicularizados pelo seu autor. Em verdade, eles existem muito mais como um registro etnográfico de uma cultura, se não já extinta, em vias de seu desaparecimento. Seria, assim, a luta da memória de preservá-los contra 0 esquecimento, além de ser um processo de sublimação em que seu poeta reencontra-se com seu passado, com seus matutos, reencontrando-se consigo mesmo. Porém, não discordamos da noção de que Um sábado seja uma comédia de costumes porque o que, em verdade, Marinho satiriza é o modus vivendi da família e, de uma maneira geral, da sociedade patriarcal. Por isso nos per- 
mitimos dizer que Um sábado em 30 é a comédia dos costumes da família patriarcal, pois consegue extrair de seus vícios, nada inócuos, motivo de riso e escárnio. Através do cômico, M arinho elabora sua crítica político-social.

Contudo, seu riso é mais que uma censura, ele é uma constatação que ressoa como a condenação da sociedade patriarcal à sua estagnação. 0 que subjaz na peça é o pessimismo do autor. Talvez o significado maior de Um sábado em 30 seja muito mais denso do que aparenta ser: um manifesto de descrença na própria capacidade de renovação e transformação do ser humano. Marinho ri, faz rir seus personagens e também nos incita ao riso, porém seu riso é amargo. Contrasta o riso infantil da criança que já foi, que se comprazia com o linguajar dos empregados, com o sorriso do adulto que constata a desigualdade entre seus irmãos; que se repete, continuamente, e cujo único fim é a morte. Seu riso é carregado do humor que busca triunfar sobre a situação angustiante que é o viver. Viver na realidade que nos oprime e que nos faz escapar ao nosso imaginário:

\footnotetext{
0 riso relaciona-se, assim, com a tragicidade da vida, mas também com a capacidade de distanciamento: o prazer de pensar, o gosto do engano e a possibilidade de subverter provisoriamente, através do jogo, a condenação à morte e tudo aquilo que a representa. Em geral visto como sinal de alegria, o riso pode revelar 0 sofrimento em toda a sua crueza (DUARTE, 2006, p. 51).
}

Luiz M arinho faz rir não apenas porque tem o domínio da carpintaria teatral ou porque consegue extrair do absurdo de nossa sociedade a comicidade que reforça nossa superioridade de caráter ou que denuncia nossa vergonhosa identificação, mas porque tem consciência do caos e da relatividade da vida, sempre em movimento e transformação. E se essa ausência de movimento persiste, do fundo de sua descrença, ainda brota a esperança da transgressão pelo poder desestabilizador que detém o riso: sua força cômica. Por isso, desmistifica ideologias e poderes estabelecidos, brincando com a linguagem e dividindo sua voz com o falar de seu povo que se torna sua fala também. Livra o leitor-espectador, pelo prazer do jogo, de seu próprio risco ao automatismo; liberta-o, mesmo que instantaneamente, do peso da vida e do medo da morte.

\section{REFERÊNCIAS}

BERGSON, Henri. [1900]. 0 riso: ensaio sobre a significação da comicidade. Trad. Ivone Castilho Benedetti. São Paulo: Martins Fontes, 2004.

DUARTE, Lélia Parreira. Ironia e humor na literatura. Prefácio Graça Paulino. Belo Horizonte: Pontifícia Universidade Católica de M inas Gerais; São Paulo: Alameda, 2006.

FREYRE, Gilberto. [1933]. Casa-Grande \& Senzala. 40. ed. Rio de Janeiro: Record, 2000.

LIM A, Luiz Costa. Sociedade e discurso ficcional. Rio de Janeiro: Ed. Guanabara, 1986. 
LIMA FILHO, Andrade. Teatro e academia. Diário de Pernambuco, Recife, 7 jan. 1981. Opinião, [s.p.].

M ARINHO, Luiz. Um sábado em 30; A incelença; A afilhada de N. S. da Conceição. Recife: Universidade Federal de Pernambuco; Imprensa Universitária, 1968.

MARINHO, Luiz. Um sábado em 30. Revista de Teatro, Rio de Janeiro, Sociedade Brasileira de Autores Teatrais, n. 459, p. 39-63, jul./ago./set. 1986.

M ARINHO, Luiz. Luiz Marinho - do teatro ao romance. Diário oficial, Recife, 29 maio. Suplemento Cultural, ano 1, n. 10, p. 8-10, 1987. Entrevista concedida aos jornalistas Christianne Müller, Mário Hélio e Nagib Jorge Neto.

M ENDES, Cleise. A força cômica. In: BIÃO, Armindo et al. Temas em contemporaneidade, imaginário e teatralidade. São Paulo: Annablume; Salvador: JIPE-CIT, 2000, p. 177-187.

PEREIRA, Nilo. Notas avulsas. Jornal do Commercio, Recife, [s/p], 2 dez. 1980.

PONTES, Joel. Um sábado em 30 (1). Diário de Pernambuco, Recife, p. 3, 13 jul. 1963.

PRADO, Décio de Almeida [1963]. Um sábado, em 30. In: Idem. Teatro em progresso: crítica teatral (1955-1964). São Paulo. Perspectiva, 2002, p. 273-275.

QUEIROZ, M aria Isaura Pereira de. 0 coronelismo numa interpretação sociológica. In: FAUSTO, Boris (Dir.). 0 Brasil republicano: estrutura de poder e economia. 2. ed. São Paulo: Difel, tomo 3, v. 1, 1977, p 153-190.

VIEIRA, Anco Márcio Tenório. Luiz Marinho: 0 sábado que não entardece. Prefácio Antonio Cadengue. Recife: Fundação de Cultura Cidade do Recife, 2004. 
